\title{
EFIKASI Bacillus thuringiensis TERHADAP HAMA ULAT DAUN GAHARU Heortia vitessoides
}

\section{(Efficacy of Bacillus thuringiensis againts Worm Leaf Pest on Tree Gaharu Producer)}

\author{
Fajar Lestari dan Edi Suryanto \\ Balai Penelitian Kehutanan Banjarbaru \\ Jl A.Yani Km 28,7 Landasan Ulin, Banjarbaru, Kalimantan Selatan \\ Telp./Fax. 0511-4707872 \\ Email : fajar@foreibanjarbaru.or.id
}

Naskah masuk : 15 Maret 2012; Naskah diterima : 29 November 2012

\begin{abstract}
Heortia vitessoides worms attack gaharu plants in Kandangan, Regency of Hulu Sungai Selatan and Barabai, Regency of Hulu Sungai Tengah, Central Kalimantan province. This pest attack causes stunted growth of the gaharu

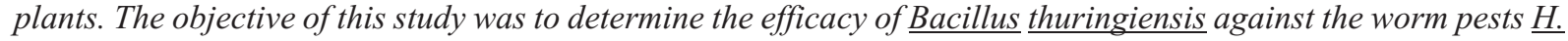
vitessoides. The study was conducted in the protected forest laboratory of the Forest Research Institution of Banjarbaru and in the region of gaharu stands in Kandangan and Barabai, South Kalimantan. The research results showed that the insecticide with the active substance $\underline{B}$. thuringiensis at a concentration of $0.5 \mathrm{~g} / \mathrm{l}$ and $1.5 \mathrm{gr} / \mathrm{l}$ effectively caused larval mortality of $100 \%$ on day 3, and the treatment with the concentration of $1 \mathrm{~g} / \mathrm{l}$ and $2 \mathrm{~g} / \mathrm{l}$ effectively caused 100\% mortality of larvae on day 2 at the laboratory scale. At the field scale all concentrations resulted in $100 \%$ larval mortality at day 3. Variations of concentrations used did not significantly affect mortality of larvae in the laboratory and on the field.
\end{abstract}

Keywords: Gaharu, Heortia vitessoides, Bacillus thuringiensis, efficacy, larvae

\begin{abstract}
ABSTRAK
Ulat Heortia vitessoides menyerang tanaman gaharu di Kandangan Kabupaten Hulu Sungai Selatan dan Barabai Kabupaten Hulu Sungai Tengah Provinsi Kalimantan Selatan. Serangan hama ini menyebabkan terjadinya gangguan pertumbuhan pada tanaman gaharu. Tujuan penelitian ini untuk mengetahui efikasi Bacillus thuringiensis terhadap hama ulat $H$. vitessoides. Penelitian dilakukan di laboratorium perlindungan hutan Balai Penelitian Kehutanan Banjarbaru dan areal tegakan gaharu di Kandangan dan Barabai, Kalimantan Selatan. Hasil penelitian menunjukkan bahwa insektisida berbahan aktif $B$. thuringiensis pada konsentrasi $0,5 \mathrm{gr} / 1$ dan 1,5gr/1 efektif menyebabkan mortalitas larva sebesar $100 \%$ pada hari ke-3, perlakuan dan konsentrasi 1 gr/l dan 2 gr/l efektif menyebabkan mortalitas larva sebesar $100 \%$ pada hari ke-2 pada skala laboratorium. Skala lapangan menunjukkan bahwa semua konsentrasi menyebabkan mortalitas larva 100\% pada hari ke-3, sementara variasi konsentrasi yang digunakan tidak berpengaruh nyata terhadap mortalitas larva pada skala laboratorium dan skala lapangan.
\end{abstract}

Kata kunci : Gaharu, Heortia vitessoides, Bacillus thuringiensis, efikasi, larva

\section{PENDAHULUAN}

Keberhasilan budidaya tanaman gaharu dapat dilakukan dengan menjaga tanaman dari kerusakan. Kerusakan tanaman disebabkan adanya serangan hama ulat daun jenis Heortia vitessoides. Serangan hama ini mengganggu pertumbuhan terutama pada umur tanaman satu sampai dengan enam tahun.

Ulat menyerang daun gaharu dengan cara memakan pucuk tanaman dan daun-daun muda, bahkan daun yang sudah tua. Pada tanaman de- ngan tingkat serangan paling berat, ulat memakan seluruh bagian daun yang ada, baik yang muda maupun yang sudah tua, sehingga banyak tanaman yang tidak berdaun/gundul. Ulat membentuk koloni (bergerombol) dalam menyerang (memakan) tanaman sehingga bagian tanaman, khususnya daun dan batang-batang muda, habis dalam waktu yang singkat. Persentase intensitas serangan mencapai 41\% (Lestari dan Suryanto, 2010).

Serangan ulat terjadi dua kali dalam satu tahun. Pada serangan pertama tanaman yang gun- 
dul masih bisa tumbuh lagi, namun saat terkena serangan yang selanjutnya tanaman langsung mati karena kecepatan tumbuh tanaman lebih lambat dibandingkan dengan pertumbuhan populasi ulat. Oleh karena itu wabah ulat ini dianggap sangat meresahkan dan merugikan petani gaharu. Salah satu pemecahan dari masalah tersebut adalah adanya upaya pengendalian.

Dewasa ini mulai digalakkan pengendalian yang ramah lingkungan. Penggunaan bakteri (mikroorganisme) Bacillus thuringiensis sebagai komponen pengendali hama dianggap efektif dalam mengendalikan hama dari ordo Lepidoptera. Tujuan penelitian ini untuk mengetahui efikasi $B$. thuringiensis terhadap hama ulat $H$. vitessoides yang diharapkan mampu memberikan sumbangan dalam mencari alternatif pengganti insektisida kimia yang digunakan selama ini.

\section{BAHAN DAN METODE}

\section{A. Tempat dan Waktu}

Penelitian ujicoba pengendalian dilakukan di Laboratorium Perlindungan Hutan BPK Banjarbaru untuk skala laboratorium, areal tegakan gaharu umur tiga tahun di Barabai Kabupaten Hulu Sungai Tengah dan empat tahun di Kandangan Kabupaten Hulu Sungai Selatan untuk skala lapangan. Pelaksanaan penelitian dilakukan pada bulan Maret sampai dengan Desember 2011.

\section{B. Bahan dan Alat}

Bahan yang digunakan dalam penelitian ini adalah ulat $H$. vitessoides instar pertama, tegakan gaharu tahun tanam 2007 dan 2008, air, $B$. thuringiensis, thally sheet, sedangkan alat yang digunakan berupa timbangan analitik, pinset, toples plastik, gelas ukur, alat pengaduk, masker, sarung tangan, sprayer, kain kelambu, cat, kamera dan alat tulis.

\section{Metode}

Parameter yang diamati pada ujicoba pengendalian ini adalah jumlah ulat yang mati. Ujicoba pengendalian dilakukan dengan menyemprotkan larutan $B$. thuringiensis pada tanaman yang diserang hama ulat. $B$. thuringiensis diperoleh dari formulasi yang dijual dipasaran.

Perlakuan yang diujicobakan untuk pengendalian hama yakni konsentrasi larutan $B$. thuri- ngiensis yaitu 0,5 gr/l; 1 gr/l; 1.5 gr/l; dan 2 gr/l. Di laboratorium ujicoba dilakukan dengan memaparkan larva pada semai. Tiap perlakuan terdiri dari 4 ulangan dan tiap ulangan dipaparkan masing-masing 5 larva. Sedangkan di lapangan, ujicoba pengendalian dilakukan dengan mengintroduksi larva pada ranting daun. Tiap perlakuan terdiri dari 3 ulangan dan tiap ulangan dipaparkan masing-masing 5 larva. Daun yang telah terintroduksi larva disemprot dengan larutan $B$. thuringiensis kemudian dibungkus dengan kain kasa agar ulat yang mengalami kematian dapat termonitoring.

Data mortalitas larva diperoleh dari persentase larva yang mati dibandingkan dengan jumlah larva keseluruhan. Perhitungan kematian larva ini dilakukan 24 jam setelah penyemprotan B. thuringiensis. Aplikasi penyemprotan dilakukan dengan menyemprotkan larutan pada seluruh daun tanaman sampai jenuh (mulai menetes).

Mortalitas larva dihitung pada setiap perlakuan konsentrasi Bacillus thuringiensis. Hasil dari pengamatan, kemudian dihitung persentase mortalitas (kematian) larva dengan rumus :

Mortalitas larva $(\%)=\frac{\sum \text { Larva yang mati }}{\Sigma \text { Larva }} \times 100 \%$

\section{Analisis Data}

Pengolahan data berdasarkan hasil di laboratorium dan lapangan. Rancangan yang dipakai Rancangan Acak Lengkap. Data hubungan antara mortalitas larva dengan konsentrasi diolah dengan analisis varian, apabila terjadi perbedaan yang nyata pada perlakuan yang dicoba maka dilanjutkan dengan uji lanjut Duncan.

\section{HASIL DAN PEMBAHASAN}

\section{A. Pengendalian Skala Laboratorium}

Mortalitas larva mulai diamati 1 hari (24 jam) setelah perlakuan (1 HSP). Mortalitas larva mulai terjadi pada hari pertama (24) jam pertama dengan persentase paling tinggi sebesar 95\% untuk konsentrasi 2 gr/l dan paling rendah sebesar $75 \%$ untuk konsentrasi $0,5 \mathrm{gr} / 1$ (Gambar 1$)$.

Hasil penelitian ujicoba menunjukkan bahwa variasi konsentrasi yang digunakan tidak berpengaruh nyata terhadap mortalitas larva. Hal ini ditunjukkan oleh hasil analisis sidik ragam $\mathrm{F}_{\text {hitung(0,05, 3, 12) }}=0,8<\mathrm{F}_{\text {tabel }}=4,47, \mathrm{p}$ value $(0,518)>$ 0,05 sehingga variasi konsentrasi yang diguna- 
Gambar (Figure) 1. Mortalitas larva pasca penyemprotan B. thuringiensis skala laboratorium (Larva mortality after spraying of Bacillus thuringiensis in laboratory scale).

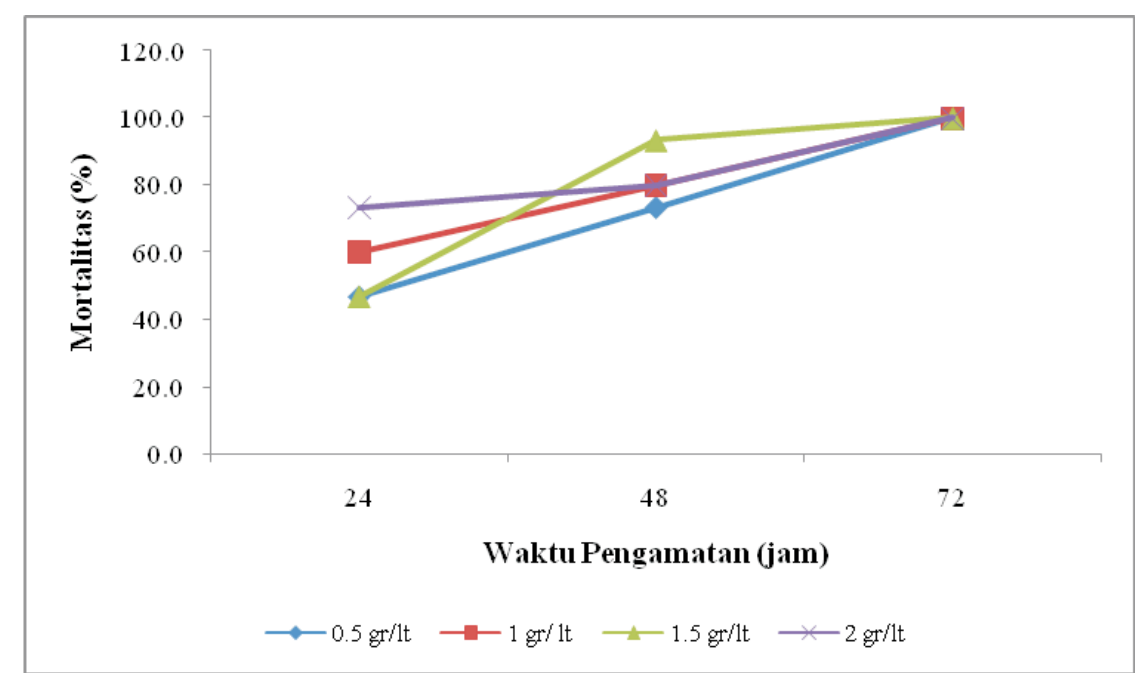

Gambar (Figure) 2. Mortalitas larva pasca penyemprotan B. thuringiensis di Kandangan (Mortality larva

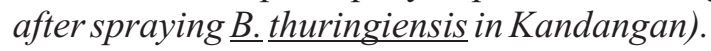

kan tidak berpengaruh nyata terhadap mortalitas larva. Penggunaan variasi konsentrasi efektif menyebabkan kematian larva $100 \%$ pada hari ke-3.

\section{B. Pengendalian Skala Lapangan}

Hasil penelitian menunjukkan bahwa pada lokasi Kandangan, variasi konsentrasi larutan yang digunakan tidak berpengaruh nyata terhadap mortalitas larva setelah 24 jam aplikasi. Hal ini ditunjukkan oleh hasil analisis sidik ragam $\mathrm{F}_{\text {hitung }(0,05,3,8)}=0,97<\mathrm{F}_{\text {tabel }}=5,42$, p value $(0,452)>$ 0,05 sehingga variasi konsentrasi yang diberikan tidak berbeda nyata menyebabkan mortalitas larva.
Variasi konsentrasi larutan pada lokasi Barabai, menunjukkan pengaruh yang nyata $\left(\mathrm{F}_{\text {hitung( }(0,05,3,8)}=9,19>\mathrm{F}_{\text {tabel }}=5,42\right)$ terhadap mortalitas larva setelah 19 jam aplikasi. Namun setelah 24 jam aplikasi, hasil penelitian menunjukkan variasi konsentrasi tidak berbeda nyata terhadap mortalitas larva $\left(\mathrm{F}_{\text {hitung(0,05,3,8) }}=3,73<\mathrm{F}_{\text {tabel }}\right.$ $=5,42$ ). Hasil uji coba lapangan dari kedua lokasi ini menunjukkan aplikasi variasi konsentrasi efektif menyebabkan kematian larva 100\% pada hari ke-3 baik di Kandangan maupun di Barabai (Gambar 2 dan 3 ). 


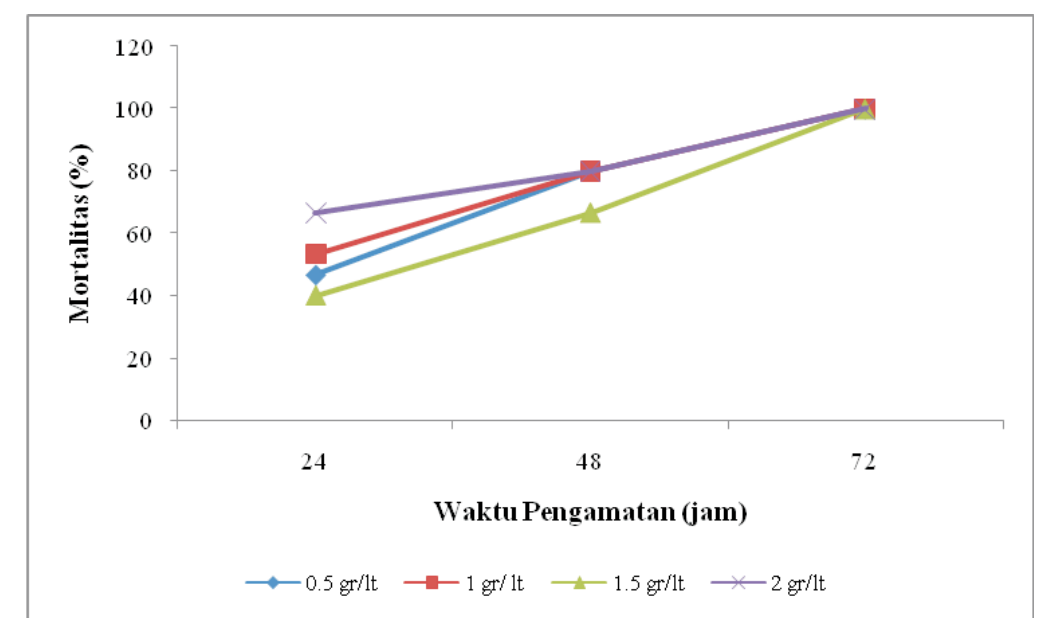

Gambar(Figure) 3. Mortalitas larva pasca penyemprotan B. thuringiensis di Barabai (Mortality larva after spraying $\underline{B}$. thuringiensis in Barabai).

Di kandangan, efektifitas ujicoba pengendalian disebabkan oleh dua faktor yakni adanya sifat toksik dari mikroba yang digunakan, dan pada saat aplikasi, larva yang digunakan berada pada stadia yang peka yaitu umur relatif muda dan berukuran kecil. Hal ini sesuai dengan pendapat Asmaliyah dan Ismail (1998) bahwa ulat Clouges glauculalis yang berukuran lebih kecil lebih peka terhadap terhadap insektisida mikroba. Waktu kematian ulat $C$. glauculalis yang berukuran kecil lebih cepat dan jumlah ulat yang mati lebih tinggi daripada ulat yang berukuran lebih besar. Secara umum, semakin dini tahap perkembangan serangan dan semakin kecil ukuran ulat maka respon ulat terhadap penggunaan insektisida semakin tinggi (peka). Pada serangga kecil, senyawa aktif diduga dapat lebih cepat mencapai bagian sasaran dalam konsentrasi yang cukup untuk menimbulkan peracunan dibandingkan pada serangga yang lebih besar (Djojosumarto, 2000) dan (Prijono, 1998 dalam Asmaliyah et al., 2006).

Hasil ujicoba laboratorium dan lapangan menunjukkan penggunaan insektisida berbahan aktif delta endotoksin dari $B$. thuringiensis efektif menyebabkan mortalitas larva. Insektisida ini bekerja sebagai racun perut murni. Racun perut ini membunuh sasaran apabila masuk kedalam organ pencernaan dan diserap oleh dinding saluran pencernaan (Djojosumarto, 2000).

Tingginya mortalitas larva selain disebabkan adanya sifat sebagai racun perut, diduga karena insektisida tersebut terserap oleh tanaman. Pada tanaman insektisida akan diangkut ke bagian-bagian tanaman ke arah akropetal melalui jaringan pengangkut xylem (Naurbauer et al., dalam Subiyakto dan Kartono, 1998, dalam
Ismail et al., 2003). Dengan demikian, daun yang telah disemprot dengan insektisida akan mengandung racun sehingga akan menggangu saluran pencernaan ulat/larva. Kondisi tersebut dapat dilihat pada jumlah mortalitas larva yang semakin tinggi di hari kedua dan ketiga.

B. thuringiensis $(\mathrm{Bt})$ pada konsentrasi $0,05 \%$ (b/v) efektif menyebabkan mortalitas larva $H$. vitessoides sebesar $100 \%$ pada hari ke-3 dan pada konsentrasi $0.1 \%(\mathrm{~b} / \mathrm{v})$ efektif menyebabkan mortalitas larva $100 \%$ pada hari ke-2 (Ngatiman et al., 2010). Aplikasi insektisida mikroba $B$. thuringiensis var.kurstaki strain $H-14$ (Bh) dan insektisida mikroba $B$. thuringiensis var. kurstaki strain EG-2371 (Be) juga dilakukan terhadap hama pemakan daun tanaman pulai darat $C$. glauculalis. Mortalitas larva paling tinggi terjadi pada hari kedua (Asmaliyah et al., 2006).

Bakteri gram positif pada bt masuk kedalam tubuh ulat H.vitessoides menyebabkan paralisis saluran pencernaan ulat. Gejala yang terlihat pada ulat yang mati adalah tubuh lunak mengandung cairan, berwarna hitam, berbau busuk dan tubuhnya hancur serta mengeluarkan cairan berwarna hitam (Gambar 4).

Toksin kristal (cry) merupakan faktor utama yang bertanggung jawab dalam menyebabkan kematian larva. Protein kristal yang termakan oleh serangga akan larut dalam lingkungan basa pada saluran pencernaan serangga. Prototoksi yang telah larut selanjutnya dipotong oleh enzim proteinase yang dihasilkan saluran pencernaan serangga menjadi toksin yang aktif. Toksin yang telah teraktivasi selanjutnya menempel pada protein reseptor yang berasosiasi dengan membran yang berada pada permukaan sel epitel usus. Penyisipan toksin pada membran apikal sel-sel 


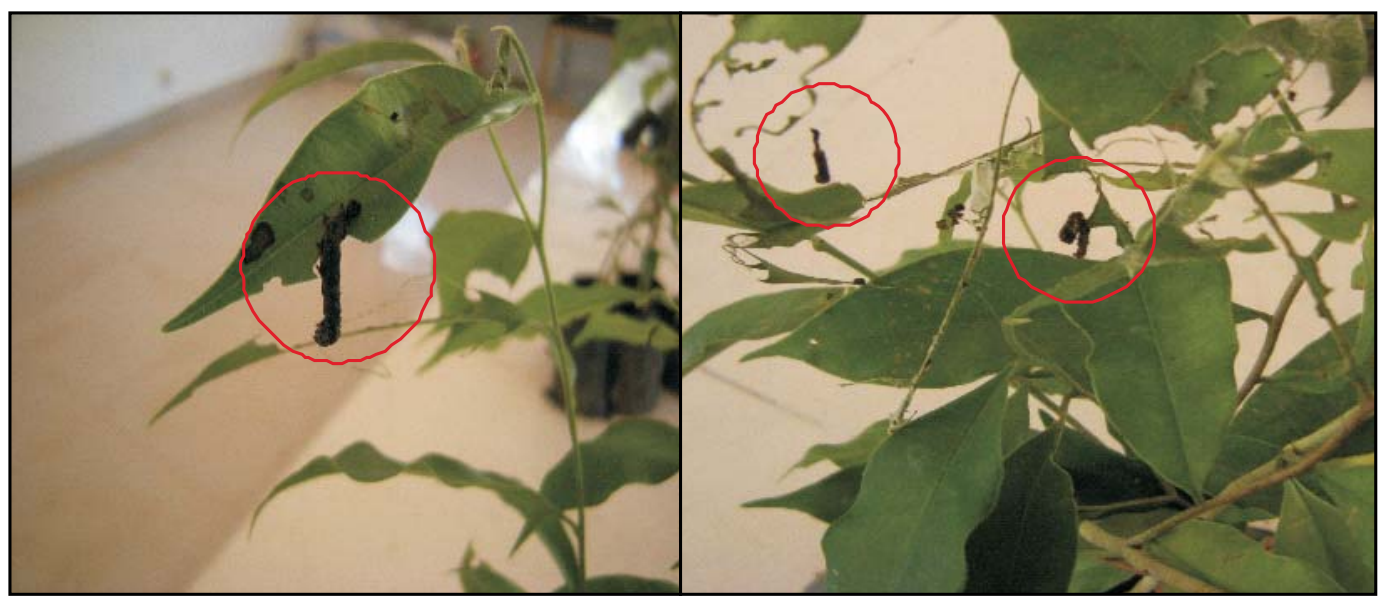

Gambar (Figure) 4. Ulat setelah disemprot B. thuringiensis (Larva after sprayed with $\underline{B}$ thuringiensis)

epitelium menginduksi terbentuknya ion channel dan pori atau lubang non spesifik sehingga mengakibatkan sel mengalami lisis (Schnepf et al., 1998).

Selain protein $c r y, B$. thuringiensis juga menghasilkan berbagai komponen lainnya yang berkontribusi dalam virulensi, diantaranya fosfolipase (Zhang et al., 1993 dalam Ngatiman et al., 2010), $\beta$-eksotoksin (Levinson, 1990 dalam Ngatiman et al., 2010), protease (Lovgren et al., 1990), dan Vegetative Insecticidal Factor (VIP) (Estrusch et al., 1996 dalam Ngatiman et al., 2010). Protein cry mempunyai spesifisitas yang tinggi, sehingga dampaknya terhadap serangga non target rendah. Sampai saat ini terdapat lebih dari 300 gen penyandi protein cry yang telah diidentifikasi, yang diklasifikasikan menjadi 51 kelompok dan sub kelompok berdasarkan similaritas sekuen asam amino (Crickmore et al., 2007 dalam Ngatiman et al., 2010).

\section{KESIMPULAN}

\section{A. Kesimpulan}

1. Variasi konsentrasi tidak berpengaruh nyata terhadap mortalitas larva $H$. vitessoides pada skala laboratorium dan lapangan.

2. Penggunaan variasi konsentrasi efektif pada skala laboratorium menyebabkan mortalitas larva $100 \%$ pada hari ke-2 untuk konsentrasi 1 gr/l dan 2 gr/l, dan pada hari ke-3 untuk konsentrasi $0,5 \mathrm{gr} / 1$ dan $1,5 \mathrm{gr} / 1$.

3. Semua konsentrasi menyebabkan mortalitas larva $100 \%$ pada hari ke-3.

\section{B. Saran}

Aplikasi penggunaan $B$. thuringiensis dapat menggunakan konsentrasi rendah yakni 0,5 $\mathrm{gr} / \mathrm{l}$ air untuk mengendalikan serangan hama ulat H. vitessoides.

\section{DAFTAR PUSTAKA}

Asmaliyah, S. Utami dan Yudhistira. 2006. Efikasi Beberapa Jenis Insektisida Terhadap Hama Pemakan Daun Pada Tanaman Pulai Darat. Jurnal Hutan Tanaman. Vol. 3 No. 2.

Djojosumarto, P. 2000. Teknik Aplikasi Pestisida Pertanian. Penerbit Kanisius. Cetakan I. Yogyakarta.

Ismail, B., A. Fiani dan H. Moko. 2003. Uji Pengendalian Hama Pada Tanaman Mahoni (Swietenia macrophylla King) dengan Beberapa Insektisida Microba d-endotoksin. Jurnal Pemuliaan Tanaman Hutan. Vol. 1 No. 3.

Lestari, F. dan E. Suryanto. 2010. Identifikasi Jenisjenis Hama dan Penyakit Gaharu. Laporan Hasil Penelitian. Balai Penelitian Kehutanan Banjarbaru. Tidak dipublikasi-kan.

Lovgren, A., M.Y. Zhang, A. Engstrom, G. Dalhammar and R. Landen. 1990. Moleculer Characterization of Immune Inhibitor A, a Secreted Virulence Protease from Bacillus thuringiensis. Mol. Microbiol. 4:2137-2146.

Ngatiman, I. Anggraini dan N. E. Lelana. 2010. Serangan Hama Heortia vitessoides Moore. pada Tanaman Penghasil Gaharu (Aquilaria microcarpa) dan Teknik Pengendaliannya. Prosisding Seminar Nasional "Kontribusi 
Litbang dalam Peningkatan Produktifitas dan Kelestarian Hutan”. Bogor 29 November 2010.

Schnepf E., N. Crickmore, J. Van Rie, D. Lereclus, J.

Baum, J. Feitelson, D.R. Zeigler. and D.
Dean. 1998. Bacillus thuringiensis and Its Pesticidal Crystal Protein. Microbiol Mol Biol Rev. 62:775-806 